\title{
Sylvilagus Brasiliensis (Linnaeus 1758) (Mammalia, Lagomorpha, Leporidae): First Record for Uruará, South Western Para State, Amazonia, Brazil
}

\author{
Roberto Portella de Andrade, Emil José Hernández-Ruz \\ ${ }^{1}$ Curso de Pós-graduação em Biodiversidade e Conservação. Universidade Federal do Pará, Campus \\ Universitário de Altamira. Rua Coronel José Porfírio, Altamira, Pará, Brazil
}

Abstract: We present the first record of Sylvilagus brasiliensis to Uruará, south western Para State, Brazil. This location is outside the known distribution of species and also outside the domain of the Cerrado biome, which is usually associated with the geographic distribution of S. brasiliensis.

The tapeti (Sylvilagus brasiliensis), Brazilian cottontail or forest cottontail is a rabbit $20-40 \mathrm{~cm}$ long (without the tail), and the adult individual may, weigh from 450 to up to 1,200 g. Their ears are short (40-61 mm) and his big dark eyes. It has elongated hind legs with four fingers while the former are shorter and five fingers. It features short, dense coat; brownish on the back and lighter on the belly. There are also sexual dimorphism, with females larger [1]. This species occurs from Tamaluipas South, Mexico along the east coast of Mexico (excluding the states of Yucatan, Quintana Roo, Campeche and) through Guatemala, (possibly) El Salvador, Honduras, eastern Nicaragua, eastern Costa Rica, Panama and through the northern half of South America (except at high altitudes), including Peru, Bolivia, Paraguay, northern Argentina and most of Brazil. Distribution in the Amazon region is unknown and extremely uneven [2, 3, 4]. In deep forest, far from human disturbance, occurring in swamps and along the edges of the river. They are not often found primary forest land away from the edges [4]. It presents nocturnal habitats alone and the diet of this species includes tender grasses and vegetables, plus roots, fruits and seeds of the understory and open areas [1]. Sylvilagus brasiliensis is the unique species of Leporidae family not exotic with geographical distribution in Brazil (Figure 1). The conservation status of the species according to the IUCN (2017) is "least concern".

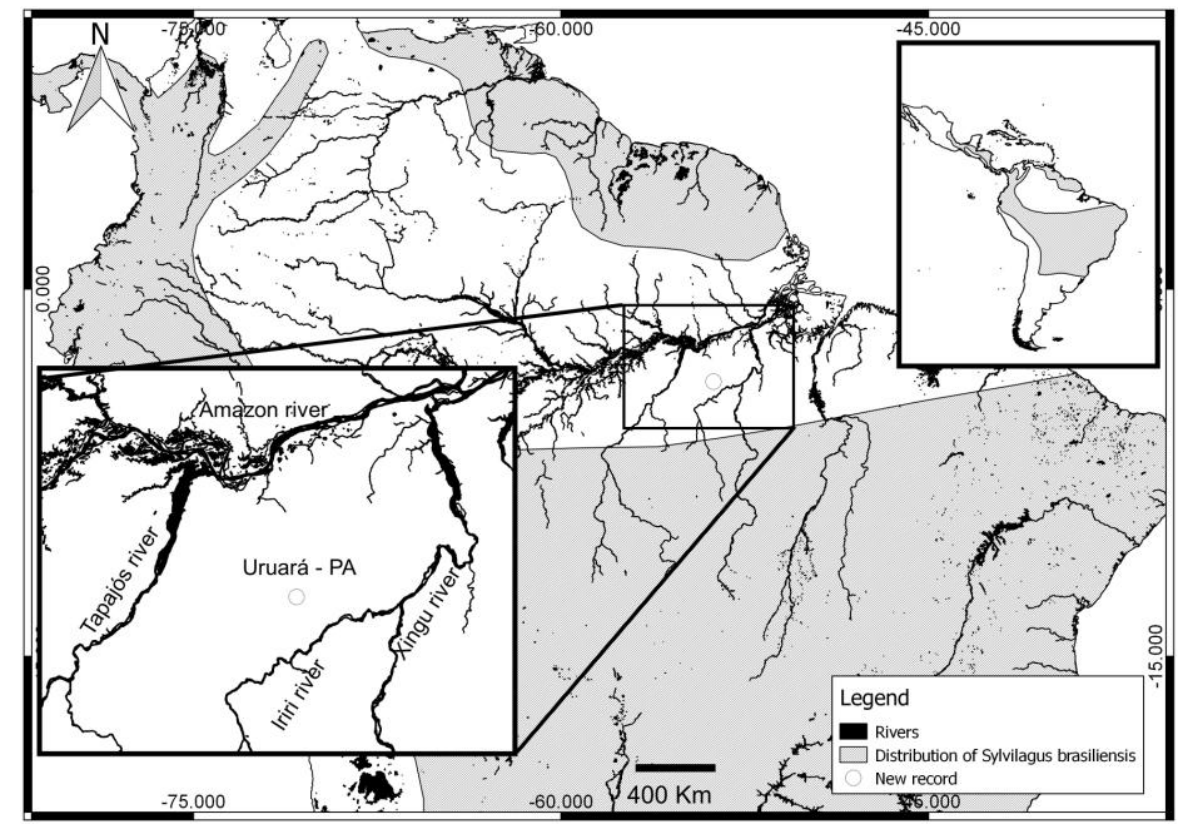

Figure1. Geographic distribution of Sylvilagus brasiliensis and the new record in the Uruará, south western Para State, Amazonia, Brazil 
To date, the species had not been recorded for municipality of Uruará (200 km of Altamira); southwestern Pará, inserted into the Amazon biome.

Considering the information presented, the occurrence of the species in the region is doubtful. However, are common nocturnal meetings on dirt roads, as well as stool samples in growing areas; and more specifically, in March 2015, was the first record of S. brasiliensis. An individual was photographed in the Vicinal do km 185 south of Transamazon highway (Lat / Lon: $3^{\circ} 46$ '52.34 "S, $53^{\circ} 46^{\prime} 32.90^{\prime \prime} \mathrm{W}$ ), characterized as pasture Figures 2 and 3).

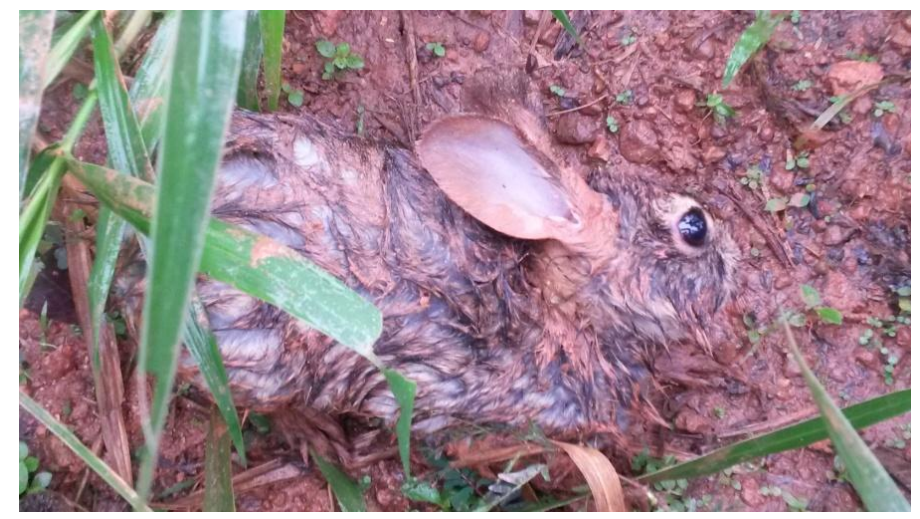

Figure2. Live view of an adult Sylvilagus brasiliensis collected at Uruará, south western Para State, Amazonia, Brazil (Photo by R. Portella).

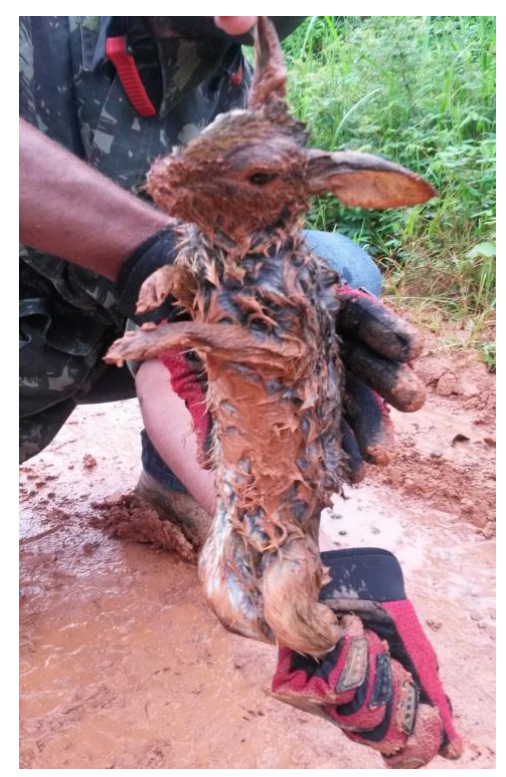

Figure3. Live ventro-lateral view of an adult Sylvilagus brasiliensis collected at Uruará, south western Para State, Amazonia, Brazil (Photo by R. Portella).

\section{DISCUSSION}

In Brazil, one of the priorities of the agencies responsible for biodiversity conservation, as well as researchers, it is to obtain concrete and updated data on the geographical distribution of species. Authors such as Reis et al [1] present the map of the distribution of the species without specific data records for the region, but in the "other ecological data" it is based on information from the closed or open areas as preferential use by the species; and they are common in the city pasture areas on the banks of primary forests.

The loss of habitat from deforestation and human settlement can pose a threat to this species, but the effect of deforestation in the abundance of S. brasiliensis is not well known [2]. In Mexico, populations declined when the habitat was cleared, but the species is known to inhabit well in pastures and secondary forests [5]. According to Durant [6], abundance of S. b. meridensis in high mountains of Venezuela was reduced to 0.04 animals / ha compared to the levels previously recorded 4.8 animals / ha due to habitat loss. Note the need for a systematic survey in respect of this kind, since the distribution is still not clearly defined, especially in regard to the Amazon region and most of the known environmental data were obtained from studies in rabbits in Páramos from Venezuela [2]. 
Sylvilagus Brasiliensis (Linnaeus 1758) (Mammalia, Lagomorpha, Leporidae): First Record for Uruará, South Western Para State, Amazonia, Brazil

\section{ACKNOWLEDGMENTS}

We thank: to Elciomar Araujo de Oliveira for preparing the map, to ICMBIO-SISBIO/BRAZIL, to provide authorization 48195-2015 for capture, collection and transport of biological material.

\section{REFERENCES}

[1] Reis, N.L.; Perachi, A.L. Fregonezi, M.N. \& B K. Rossaneis (eds.). 2010. Mamíferos do brasil: guia de identificação. Technical books. 557p. Rio de Janeiro.

[2] Chapman, J. A. And Ceballos, G. 1990. Chapter 5: The Cottontails. In: J. A. Chapman and J. C. Flux (eds.), Rabbits, hares and pikas: status survey and conservation action plan, pp. 95-110. IUCN, Gland, Switzerland. 168 pp.

[3] Hoffmann, R. S. And Smith, A. T. 2005. Order Lagomorpha. In: D. E. Wilson and D. M. Reeder (eds), Mammal Species of the World, pp. 185-211. Johns Hopkins University Press, Baltimore, Maryland, USA.

[4] Emmons, L. H. \& Feer, F. Neotropical Rainforest mammals. A Field Guide, Second Edition. The University Chicago Press, Chicago, 307p., 1997.

[5] Alvarez De Toro, M. 1977. Los Mamiferos de Chiapas. Gobierno del Estado, Tuxtla Gutiérrez, CS, México.

[6] DURANT, P., 1986. Relaciones filogenéticas y ecología del conejo de páramo andino. Monog., 6. CDCHT y Consejo de Publs. Universidad de los Andes. Mérida. Venezuela.

[7] Mexican Association for Conservation and Study of Lagomorphs (AMCELA), Romero Malpica, F.J. \& Rangel Cordero, H. 2008. Sylvilagus brasiliensis. The IUCN Red List of Threatened Species 2008. T41298A10418161. http://dx.doi.org/10.2305/IUCN.UK.2008.RLTS.T 41298A10 418161.en. Downloaded on 12 June 2017. 